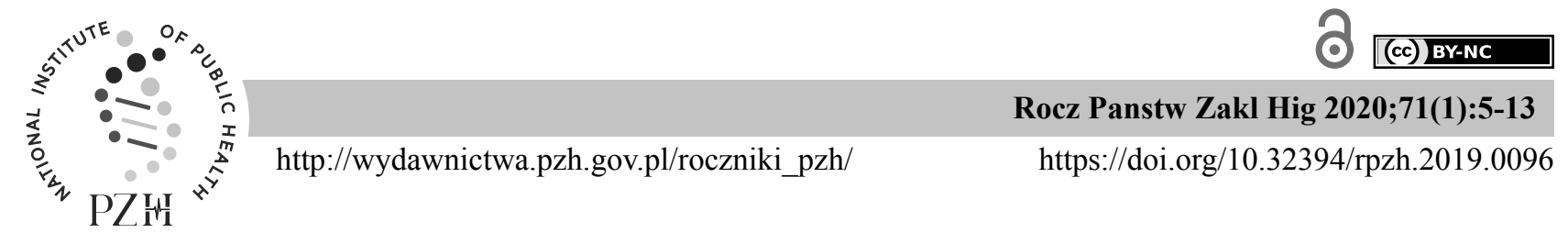

\title{
ROLE OF FRUIT AND VEGETABLES FOR THE MENTAL HEALTH OF CHILDREN: A SYSTEMATIC REVIEW ${ }^{1}$
}

\author{
Dominika Guzek', Dominika Gtabska², Barbara Groele², Krystyna Gutkowska \\ ${ }^{1}$ Department of Food Market and Consumer Research, Institute of Human Nutrition, \\ Warsaw University of Life Sciences-SGGW, Warsaw, Poland \\ ${ }^{2}$ Department of Dietetics, Institute of Human Nutrition, Warsaw University of Life Sciences-SGGW, \\ Warsaw, Poland
}

\begin{abstract}
Background. About 10-20\% of children and adolescents worldwide experience a mental health problems, while among the factors which may be preventive, there is a diet, especially fruit and vegetables intake.

Objective. The aim of the study was to conduct a systematic review of the observational studies analyzing the association between the fruit and vegetables intake and the mental health in pre-schoolers and school-aged children.

Material and methods. The systematic review was conducted based on PubMed and Web of Science databases, while the human studies, published in English until June 2019, conducted in populations of pre-schoolers and/ or school-aged children, verifying the influence of fruit and/ or vegetables and products (e.g. juices) intake on a various aspects of mental health were included.

Results. The number of 12 studies were included, while a wide area of aspects of mental health was taken into account, including general well-being, emotions, stress, behavioral difficulties and problems, as well as depressive symptoms, or depressive symptoms combined with anxiety.

Conclusions. In majority of studies included to the systematic review of the observational studies analyzing the association between the fruit and vegetables intake and mental health in pre-schoolers and school-aged children, the supposed positive influence was confirmed. However, it must be indicated that it was studied only in a few research and the issue must be analyzed in other populations. At the same time, in a number of studies, not fruit and vegetables intake alone was stated to be beneficial, but rather a more general dietary pattern, including also other elements of healthy diet and healthy lifestyle.
\end{abstract}

Key words: fruit, vegetables, juices, mental health, child, diet

\section{STRESZCZENIE}

Wprowadzenie. Zaburzenia psychiczne są obecnie coraz powszechniejszym problemem zdrowotnym, dotykającym około 10-20\% dzieci i młodzieży, podczas gdy wśród czynników mających znaczenie w profilaktyce wskazuje się prawidłową dietę, w tym szczególnie spożycie warzyw i owoców.

Cel badań. Celem badań było przeprowadzenie przeglądu systematycznego badań obserwacyjnych dotyczących zależności między spożyciem warzyw i owoców a zdrowiem psychicznym u dzieci w wieku przedszkolnym i szkolnym.

Material i metody. Przegląd systematyczny przeprowadzono w oparciu o bazy PubMed i Web of Science i włączono badania z udziałem ludzi, opublikowane w języku angielskim do czerwca 2019 włącznie, realizowane w populacjach dzieci w wieku przedszkolnym i/ lub szkolnym, które weryfikowały wpływ spożycia warzyw i/ lub owoców oraz ich przetworów (w tym soków) na różne aspekty zdrowia psychicznego.

Wyniki. Włączono 12 badań, obejmujących szeroki zakres czynników związanych ze zdrowiem psychicznym, takich jak generalny dobrostan, emocje, stres, zaburzenia i problemy związane z zachowaniem, jak również objawy depresyjne, lub objawy depresyjne w połączeniu z niepokojem.

Wnioski. W większości badań włączonych do systematycznego przeglądu badań obserwacyjnych oceniających zależność między spożyciem warzyw i owoców a zdrowiem psychicznym u dzieci w wieku przedszkolnym i szkolnym, spodziewana zależność została potwierdzona. Jednakże, należy wskazać, że była ona do tej pory analizowana w niewielu badaniach i należałoby problem ten oceniać także w innych populacjach. Równocześnie, w wielu badaniach, to nie samo spożycie warzyw i owoców było określone jako korzystne, ale raczej obserwowano wpływ generalnych wzorców żywieniowych, obejmujących także inne elementy diety i prozdrowotnego stylu życia.

\section{Słowa kluczowe: owoce, warzywa, soki, zdrowie psychiczne, dzieci, dieta}

1 The study was financed by the Certified Product 'CP' Quality System (CEN.DRR.WFP.705.350.2018.MR.3) within the National Polish Promotion Fund for Fruits and Vegetables Consumption.

Corresponding author: Dominika Guzek, Department of Food Market and Consumer Research, Institute of Human Nutrition, Warsaw University of Life Sciences-SGGW, Nowoursynowska Street 159c, 02-776 Warsaw, Poland, phone: +48 22 5937134, fax: +48 22 5937018, e-mail: dominika_guzek@sggw.pl

(C) Copyright by the National Institute of Public Health - National Institute of Hygiene 


\section{INTRODUCTION}

The World Health Organization (WHO) emphasizes that about $10-20 \%$ of children and adolescents worldwide experience a mental health problems, being a leading cause of disabilities in case of young people [26]. Taking it into account, the issues associated with the mental health of children are currently becoming a serious public health issue, being integrated into general medical and primary care, as both mental health promotion and early interventions are indicated among global priorities [27]. Problems associated with mental health of children are experienced in a school settings [23] and in families [22], but the major issue is how to provide an adequate help for children and support them in their situation [25].

A systematic review of primary care practitioners' perceptions by O'Brien et al. [18] emphasized the role of significant barriers in primary care for mental health problems, including a lack of providers and resources, extensive waiting lists, and financial restrictions, that were identified as main obstacles for managing the problem. Taking them into account, the prevention is becoming even more vital, as preventive programs may be effective to assure not only proper mental health for the period of childhood, but also adolescence and adulthood [24].

Among the factors which are associated with a mental health of children, there is a diet, being suggested as associated with the depression risk [13] and other mental health problems [19]. Especially the systematic review by O'Neil et al. [20] highlight the potential importance of the relationship between dietary patterns, or diet quality and mental health in childhood. However, there is a need to indicate a specific recommendations associated with mental health problems prevention, so it is necessary to verify the influence of a specific dietary behaviors on a general mental health, while among suggested food products and nutrients there are: fruit and vegetables, whole grains, fish, lean meat, olive oil, folate, B vitamins, magnesium, selenium, zinc, Monounsaturated Fatty Acids (MUFA), Polyunsaturated Fatty Acids (PUFA), polyphenols and fiber [12]. Especially for fruit and vegetables, there are some proofs, as for young ones a low fruit and vegetables intake is a longitudinal correlate of poor mental health [10] and young ones with depression commonly do not follow the recommendations of fruit and vegetables intake [9].

However, especially for school children obtaining the recommended intake of fruit and vegetables may be straitened, as their common reluctance or avoidance of unknown food products causes that they often limit the fruit and vegetables intake [7,8]. It corresponds the inadequate fruit and vegetables intake that is commonly observed in various populations of children, including Polish one $[6,11]$. Taking it into account, the aim of the presented study was to conduct a systematic review of the observational studies analyzing the association between the fruit and vegetables intake and the mental health in pre-schoolers and school-aged children.

\section{MATERIAL AND METHODS}

The systematic review was conducted based on PubMed and Web of Science databases, while the basic search strategy was to include human studies, conducted in populations of pre-schoolers and/ or school-aged children, verifying the influence of fruit and/ or vegetables intake (both as a separate nutritional factor and within the broader characteristics of diet). Only peer-reviewed studies were included, which were published in English until June 2019, while both indicated databases were searched and the additional manual search of the references of included studies was applied.

For the assessment of fruit and vegetables intake, both studies of the fresh unprocessed products were taken into account, and the studies which included the intake of juices, based on the proven role of juices in obtaining a recommended 5-a-day recommendation for fruit and vegetables intake [2]. However, only habitual intake was taken into account and the studies of a short-term dietary interventions were excluded.

For the assessment of mental health, all the aspects were allowed, both in healthy populations and populations with any chronic or acute diseases, while excluding only potential groups with intellectual disabilities, dementia, Attention Deficit Hyperactivity Disorder (ADHD) or eating disorders. The applied search strategy included the criteria for fruit and/ or vegetables intake and mental health, while afterwards the extracted studies were searched once again to include only those conducted for a groups of preschoolers and school-aged children. Detailed search strategy is presented in the Table 1 and the search procedure is presented in the Figure 1. The studies were searched independently by 2 researchers based on the titles and afterwards verified by them based on the abstracts, as well as based on the extracted full texts. Any disagreement between researchers was discussed and the final decision was made after consultation with the third researcher. If needed, the authors of the study were asked for the full text of their manuscript.

While the studies were included to the systematic review, the following data were extracted: author, country/location, study group, number of participants, gender proportions, age, method of assessment of fruit and vegetable intake, other fruit and vegetable products included, method of outcome assessment, psychological measure, observations, and conclusions. The results were organized in tables and the narrative review was prepared based on the gathered information. 


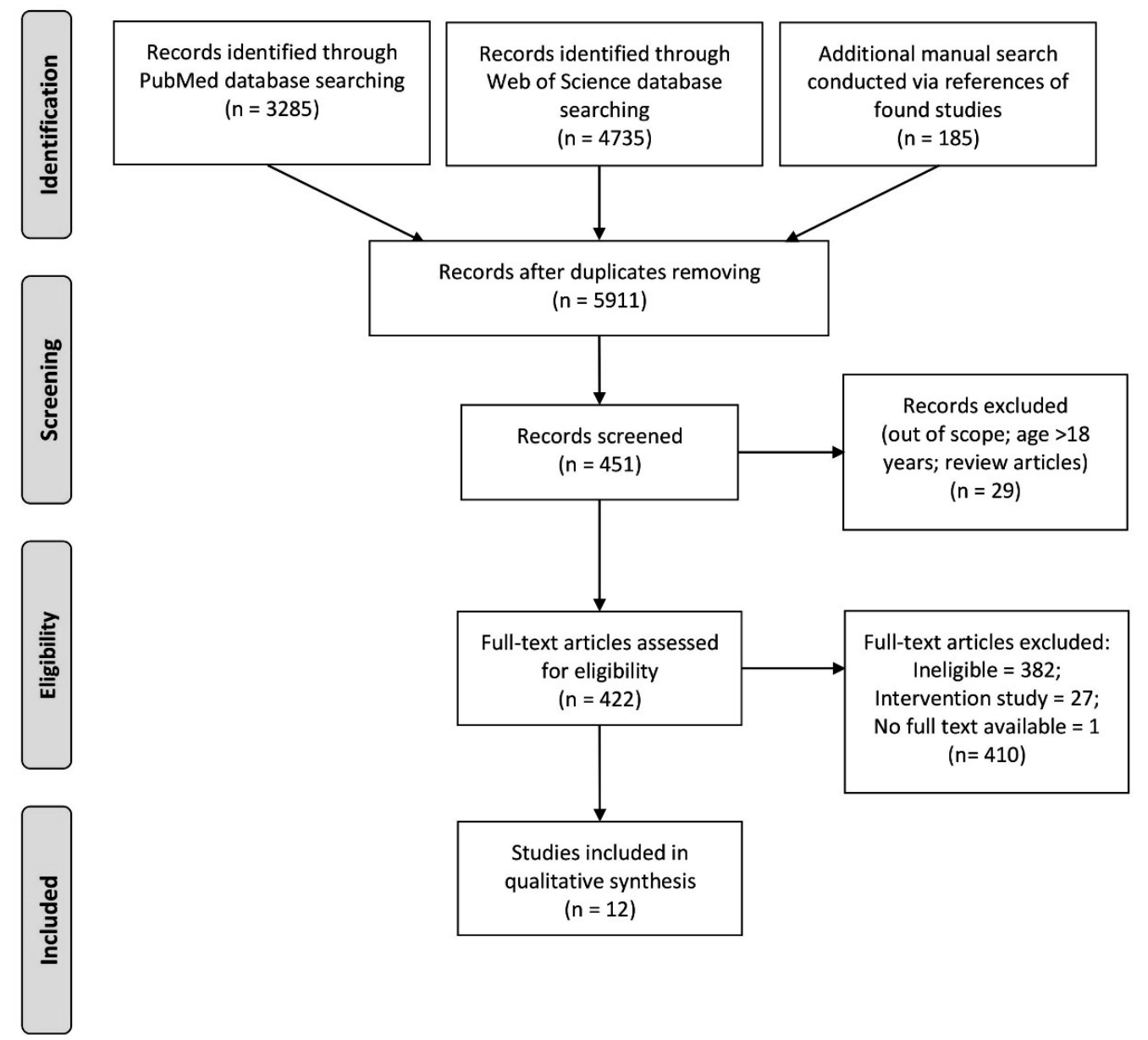

Figure 1. Flow chart of inclusion studies verifying the influence of fruit and vegetables intake on the mental health in children

Table 1. The search strategy detailed for PubMed and Web of Science databases to verify the influence of fruit and vegetables intake on the mental health in children

\begin{tabular}{|c|c|}
\hline Database & The applied full electronic search strategy \\
\hline PubMed & $\begin{array}{l}\text { (((fruit[Title/Abstract] OR fruits[Title/Abstract] OR vegetable[Title/Abstract] OR vegetables[Title/ } \\
\text { Abstract] OR juice[Title/Abstract] OR juices[Title/Abstract])) AND (mental health[Title/Abstract] } \\
\text { OR mental disorder[Title/Abstract] OR mental disorders[Title/Abstract] OR psychological } \\
\text { distress[Title/Abstract] OR mood disorders[Title/Abstract] OR depression[Title/Abstract] } \\
\text { OR anxiety[Title/Abstract] OR suicide[Title/Abstract] OR suicidal[Title/Abstract] OR well- } \\
\text { being[Title/Abstract] OR wellbeing[Title/Abstract] OR quality of life[Title/Abstract] OR self- } \\
\text { esteem[Title/Abstract] OR self esteem[Title/Abstract] OR self-efficacy[Title/Abstract] OR self } \\
\text { efficacy[Title/Abstract] OR resilience[Title/Abstract] OR empowerment[Title/Abstract] OR life } \\
\text { skills[Title/Abstract] OR social participation[Title/Abstract] OR mental capital[Title/Abstract] OR } \\
\text { emotional[Title/Abstract] OR psychosocial[Title/Abstract] OR psychology[Title/Abstract] OR } \\
\text { psychiatry[Title/Abstract])) NOT (animal NOT (animal AND human)[MeSH Terms]) }\end{array}$ \\
\hline Web of Science & $\begin{array}{l}\text { (TS=(fruit OR fruits OR vegetable OR vegetables OR juice OR juices) AND TS=("mental health" } \\
\text { OR "mental disorder" OR "mental disorders" OR "psychological distress" OR "mood disorder" } \\
\text { OR depression OR anxiety OR suicide OR suicidal OR well-being OR wellbeing OR "quality } \\
\text { of life" OR self-esteem OR "self esteem" OR self-efficacy OR "self efficacy" OR resilience OR } \\
\text { empowerment OR "life skills" OR "social participation" OR "mental capital” OR emotional OR } \\
\text { psychosocial OR psychology OR psychiatry) NOT TS=(animal NOT (animal AND human))) }\end{array}$ \\
\hline
\end{tabular}

\section{RESULTS}

The number of 12 studies were included to the systematic review based on the described inclusion procedure. The characteristics of the studied group for the included studies verifying the influence of fruit and vegetables intake on the mental health in children is presented in Table 2. 
Table 2. The characteristics of the studied group for the included studies verifying the influence of fruit and vegetables intake on the mental health in children

\begin{tabular}{|c|c|c|c|c|c|}
\hline $\begin{array}{l}\text { Ref } \\
\text { No }\end{array}$ & Author, year & Country/ Location & $\begin{array}{l}\text { Studied group of } \\
\text { children }\end{array}$ & $\begin{array}{c}\text { Number of } \\
\text { patients (girls) }\end{array}$ & Age \\
\hline$[1]$ & Banta et al. 2013 & USA/ California & $5-11$ years & $11,190(5,442)$ & $5-11$ years \\
\hline$[3]$ & Cartwright et al. 2003 & $\begin{array}{l}\text { UK/ South } \\
\text { London }\end{array}$ & $\begin{array}{l}\text { Children observed } \\
\text { for } 8 \text { years from } \\
\text { the age of } 11-12 \text { to } \\
15-16\end{array}$ & $\begin{array}{l}4,320(1,742) \text { at } \\
\text { baseline }\end{array}$ & $11.8 \pm 0.3$ \\
\hline$[4]$ & Clevenger et al. 2018 & $\begin{array}{l}\text { USA/ Flint, } \\
\text { Michigan }\end{array}$ & $\begin{array}{l}\text { Children from } 4^{\text {th }}- \\
6^{\text {th }} \text { grade }\end{array}$ & $754(354)$ & $8-13$ years \\
\hline$[5]$ & Dennison-Farris et al. 2017 & USA/ Oklahoma & $\begin{array}{l}\text { American Indian } \\
\text { children }\end{array}$ & $121(73)$ & $10.5 \pm 1.6$ \\
\hline$[14]$ & Kim et al. 2017 & Korea/ Seoul & $6-19$ years & $318(168)$ & $11.8 \pm 3.6$ \\
\hline$[15]$ & Kohlboeck et al. 2012 & Germany & Children & $3,361(1,649)$ & $11.2 \pm 0.5$ \\
\hline [16] & McMartin et al. 2012 & $\begin{array}{l}\text { Canada/ Nova } \\
\text { Scotia }\end{array}$ & $10-11$ years & $3,757(1,954)$ & $10-11$ years \\
\hline$[17]$ & Michels et al. 2012 & Belgium & $5-12$ years & 437 (219) & $\begin{array}{l}\text { Median of } 8.96 \\
\text { (girls)/ } 9.02 \\
\text { (boys) }\end{array}$ \\
\hline [19] & Oellingrath et al. 2013 & $\begin{array}{l}\text { Norway/ } \\
\text { Telemark County }\end{array}$ & $12-13$ years & 789 (393) & $12-13$ years \\
\hline$[21]$ & Renzaho et al. 2012 & Australia/ Victoria & $4-12$ years & $3,370(1,625)$ & $4-12$ years \\
\hline [28] & $W u$ et al. 2016 & $\begin{array}{l}\text { Taiwan/ Taipei } \\
\text { city and } \\
\text { Hsinchu County }\end{array}$ & $\begin{array}{l}\text { Children observed } \\
\text { for } 8 \text { years from } \\
\text { the age of } 8-9 \text { to } \\
16-17\end{array}$ & $2,259(1,129)$ & $8-17$ years \\
\hline [29] & $Y u$ et al. 2018 & China/ Wuhan & Obese children & $188(42)$ & $9.8 \pm 0.7$ \\
\hline
\end{tabular}

The assessment of the fruit and vegetable dietary intake and the psychological outcome for the included studies verifying the influence of fruit and vegetables intake on the mental health in children is presented in Table 3.
The results and conclusions for the included studies verifying the influence of fruit and vegetables intake on the mental health in children are presented in Table 4.

Table 3. The assessment of the fruit and vegetable dietary intake and the psychological outcome for the included studies verifying the influence of fruit and vegetables intake on the mental health in children

\begin{tabular}{|c|c|c|c|c|}
\hline $\begin{array}{l}\text { Ref } \\
\text { No }\end{array}$ & $\begin{array}{c}\text { Applied method of fruit and } \\
\text { vegetable dietary intake } \\
\text { assessment }\end{array}$ & $\begin{array}{l}\text { Potentially included juices } \\
\text { and other fruit/ vegetable } \\
\text { products }\end{array}$ & Assessed outcome & $\begin{array}{c}\text { Psychological measure } \\
\text { of outcome }\end{array}$ \\
\hline$[1]$ & $\begin{array}{l}\text { Question about number of } \\
\text { servings yesterday with the } \\
\text { serving size }\end{array}$ & $\begin{array}{l}100 \% \text { fruit juice included to } \\
\text { the study }\end{array}$ & Mental health & $\begin{array}{l}\text { Strengths and Difficulties } \\
\text { Questionnaire (SDQ) }\end{array}$ \\
\hline$[3]$ & $\begin{array}{l}\text { Food frequency questionnaire } \\
\text { with } 34 \text { food items; } \\
\text { Dietary Instrument for } \\
\text { Nutrition Education (DINE) - } \\
2 \text { items for typical frequency } \\
\text { of consumption of fruit and } \\
\text { vegetables }\end{array}$ & - & Perceived stress & $\begin{array}{l}\text { Perceived Stress Scale } \\
\text { (PSS) }\end{array}$ \\
\hline
\end{tabular}




\begin{tabular}{|c|c|c|c|c|}
\hline $\begin{array}{l}\text { Ref } \\
\text { No }\end{array}$ & $\begin{array}{l}\text { Applied method of fruit and } \\
\text { vegetable dietary intake } \\
\text { assessment }\end{array}$ & $\begin{array}{l}\text { Potentially included juices } \\
\text { and other fruit/ vegetable } \\
\text { products }\end{array}$ & Assessed outcome & $\begin{array}{l}\text { Psychological measure } \\
\text { of outcome }\end{array}$ \\
\hline$[4]$ & $\begin{array}{l}\text { The School Physical Activity } \\
\text { and Nutrition Survey }\end{array}$ & - & $\begin{array}{l}\text { (1) Mindfulness } \\
\text { (2) Health-related quality } \\
\text { of life }\end{array}$ & $\begin{array}{l}\text { (1) The Child and } \\
\text { Adolescent Mindfulness } \\
\text { Measure } \\
\text { (2) Kidscreen-27 }\end{array}$ \\
\hline$[5]$ & $\begin{array}{l}\text { Items from the Youth Risk } \\
\text { Behavior Surveillance survey } \\
\text { - question about the typical } \\
\text { frequency of consumption }\end{array}$ & $\begin{array}{l}\text { Sweetened juices not } \\
\text { included to fruit/ vegetables } \\
\text { but to sugar-sweetened } \\
\text { beverages }\end{array}$ & Depressive symptoms & $\begin{array}{l}\text { Child Depression Inventory } \\
\text { (27-items) }\end{array}$ \\
\hline$[14]$ & $\begin{array}{l}\text { Food frequency questionnaire } \\
\text { with } 76 \text { food items }\end{array}$ & - & $\begin{array}{l}\text { (1) Depression symptoms } \\
\text { (2) Anxiety }\end{array}$ & $\begin{array}{l}\text { (1) Child Depression } \\
\text { Inventory (CDI) } \\
\text { (2) State-Trait Anxiety } \\
\text { Inventory-State (STAI-S)/ } \\
\text { State-Trait Anxiety } \\
\text { Inventory-Trait (STAI-T) }\end{array}$ \\
\hline$[15]$ & $\begin{array}{l}\text { Food frequency questionnaire } \\
\text { with } 82 \text { food items }\end{array}$ & $\begin{array}{l}\text { Fruit juices/nectars not } \\
\text { included to fruit/ vegetables } \\
\text { but to beverages }\end{array}$ & Behavioral problems & $\begin{array}{l}\text { Strengths and Difficulties } \\
\text { Questionnaire (SDQ) }\end{array}$ \\
\hline$[16]$ & $\begin{array}{l}\text { Harvard Youth/Adolescent } \\
\text { Food Frequency Questionnaire } \\
\text { (YAQ) }\end{array}$ & - & $\begin{array}{l}\text { Internalizing disorders } \\
\text { (symptoms of depression } \\
\text { and anxiety: low mood, } \\
\text { inhibition, excessive } \\
\text { worrying, physical } \\
\text { complaints, trouble } \\
\text { sleeping, shyness) }\end{array}$ & $\begin{array}{l}\text { Diagnosis based on } \\
\text { International Classification } \\
\text { of Diseases (ICD-9/ ICD- } \\
\text { 10) }\end{array}$ \\
\hline$[17]$ & $\begin{array}{l}\text { The Children's Eating } \\
\text { Habits Questionnaire - Food } \\
\text { Frequency } \\
\text { Questionnaire (FFQ) }\end{array}$ & $\begin{array}{l}\text { Fruit and vegetables } \\
\text { including freshly squeezed } \\
\text { fruit juice }\end{array}$ & $\begin{array}{l}\text { (1) Problems } \\
\text { (2) Life events } \\
\text { (3) Daily events: hassles } \\
\text { and uplifts } \\
\text { (4) Emotions } \\
\text { (5) Coping }\end{array}$ & $\begin{array}{l}\text { (1) Strengths and } \\
\text { Difficulties } \\
\text { Questionnaire (SDQ) } \\
\text { (2) Coddington Life Events } \\
\text { Scale for children (CLES-C) } \\
\text { (3) Children's daily hassles } \\
\text { (CHS) and daily uplifts } \\
\text { (CUS) scales } \\
\text { (4) Likert-scale for how } \\
\text { they felt recently } \\
\text { (5) Question about what } \\
\text { they usually do when } \\
\text { confronted } \\
\text { with problems or when are } \\
\text { upset }\end{array}$ \\
\hline [19] & $\begin{array}{l}\text { Food Frequency Questionnaire } \\
\text { to assess dietary patterns } \\
\text { including 'Varied Norwegian' } \\
\text { dietary pattern (recommended } \\
\text { nutrient-dense foods like } \\
\text { fruits, vegetables, unrefined } \\
\text { grains and fish combined with } \\
\text { regular meals) }\end{array}$ & - & Mental health problems & $\begin{array}{l}\text { Strengths and Difficulties } \\
\text { Questionnaire (SDQ) }\end{array}$ \\
\hline [21] & $\begin{array}{l}\text { Question about the typical } \\
\text { number of servings per day }\end{array}$ & $\begin{array}{l}\text { Diced, canned and dried fruit } \\
\text { included to fruits }\end{array}$ & Child behavior difficulty & $\begin{array}{l}\text { Strengths and Difficulties } \\
\text { Questionnaire (SDQ) }\end{array}$ \\
\hline$[28]$ & $\begin{array}{l}\text { Unhealthy eating behaviors } \\
\text { measured with three questions } \\
\text { (fast foods, snacks, sugar } \\
\text { sweetened beverages) }\end{array}$ & $\begin{array}{l}\text { Sweetened juice included to } \\
\text { sugar sweetened beverages }\end{array}$ & Depressive symptoms & $\begin{array}{l}\text { Kovacs' Children's } \\
\text { Depression Inventory (CDI)/ } \\
\text { Center for Epidemiological } \\
\text { Studies Depression Scale } \\
\text { for Children }\end{array}$ \\
\hline [29] & $\begin{array}{l}\text { Question about the typical } \\
\text { number of servings per day } \\
\text { during the last month }\end{array}$ & - & $\begin{array}{l}\text { (1) Well-being } \\
\text { (2) Depressive symptoms }\end{array}$ & $\begin{array}{l}\text { (1) WHO-5 well-being } \\
\text { index (WHO-5) } \\
\text { (2) Depression } \\
\text { Self-rating Scale for } \\
\text { Children (DSRSC) }\end{array}$ \\
\hline
\end{tabular}


Table 4. The results and conclusions for the included studies verifying the influence of fruit and vegetables intake on the mental health in children

\begin{tabular}{|c|c|c|}
\hline Ref No & Results & Conclusions \\
\hline$[1]$ & $\begin{array}{l}\text { Adjusting for relevant socio-demographic characteristics, logistic } \\
\text { regression found poor mental health to be significantly associated } \\
\text { with no consumption of vegetables (OR } 0.6, p=0.005 \text { ) on the } \\
\text { previous day. }\end{array}$ & $\begin{array}{l}\text { Children with poor mental health are more likely } \\
\text { to consume calorie-dense but nutrient-poor foods } \\
\text { compared to their counterparts. Intake of such } \\
\text { foods may contribute to worse physical health as } \\
\text { these children mature. }\end{array}$ \\
\hline$[3]$ & $\begin{array}{l}\text { Girls reported more stress than boys, } \mathrm{t}(3709)=-4.39, \mathrm{p}<0.01 \\
\text { (two-tailed), } \mathrm{d}=0.15 \text {, and a higher fruit and vegetable intake, } \\
\mathrm{t}(4145)=-2.23, \mathrm{p}=0.03 \text { (two-tailed), } \mathrm{d}=0.07 \text {. In the multivariate } \\
\text { analyses, higher perceived stress was associated with an increased } \\
\text { likelihood of being in the unhealthy outcome group (Wald statistic) } \\
\text { for fruit and vegetable consumption, } \chi 2(4)=13.68, \mathrm{p}<0.01 \text { while } \\
\text { simultaneously controlling for gender, weight, ethnicity, and SES. } \\
\text { A trend also emerged for fruit and vegetable intake, for which greater } \\
\text { stress was associated with a reduced likelihood of consuming five or } \\
\text { more fruit and vegetables daily. }\end{array}$ & $\begin{array}{l}\text { Stress may contribute to long-term disease risk by } \\
\text { steering the diet in a more unhealthy direction. }\end{array}$ \\
\hline$[4]$ & Mindfulness was unrelated to both vegetable and fruit intake. & $\begin{array}{l}\text { Mindfulness was positively related to } \\
\text { psychological quality of life and inversely related } \\
\text { to junk food intake and parent- and autonomy- } \\
\text { related quality of life. }\end{array}$ \\
\hline$[5]$ & $\begin{array}{l}\text { Depressive symptoms in children were not associated with } \\
\text { consumption of fruit, salad, potatoes, carrots, other vegetables, sweet } \\
\text { juice, as well as fruit and vegetables intake combined. }\end{array}$ & $\begin{array}{l}\text { Depressive symptoms were associated with } \\
\text { dieting and screen time. }\end{array}$ \\
\hline$[14]$ & $\begin{array}{l}\text { Higher scores on the CDI, STAI-S, and STAI-T indicate negative } \\
\text { emotions, and these scores were significantly decreased from the first } \\
\text { to the fourth quartiles. Intakes of natural foods such as legumes and } \\
\text { fruits correlate with lower theta/beta ratios }(\mathrm{p}<0.05) \text {. }\end{array}$ & $\begin{array}{l}\text { There is a link between overall nutritional } \\
\text { behavior, and emotion in apparently healthy } \\
\text { children. }\end{array}$ \\
\hline$[15]$ & $\begin{array}{l}\text { A higher diet quality score was associated with lower likelihood } \\
\text { of emotional symptoms (OR adj } 0.89,95 \% \text { CI } 0.80-0.98) \text {. The } \\
\text { unadjusted significant relationship between diet quality and } \\
\text { hyperactivity/inattention was attenuated by adjusting for several } \\
\text { confounders to an OR adj of } 0.92(95 \% \text { CI } 0.82-1.03) \text {. }\end{array}$ & $\begin{array}{l}\text { Lower diet quality is associated with a higher } \\
\text { likelihood of emotional symptoms in children. }\end{array}$ \\
\hline$[16]$ & $\begin{array}{l}\text { Diet quality was not found to be associated with internalizing } \\
\text { disorder in a statistically significant manner (incidence rate ratio } \\
=1.09 ; 95 \% \text { CI } 0.73-1.63 \text { ). However, relative to children with } \\
\text { little variety in their diets, children with greater variety in their diet } \\
\text { had statistically significant lower rates of internalizing disorder in } \\
\text { subsequent years (incidence rate ratio }=0.45 ; 95 \% \text { CI } 0.25-0.82 \text { ). }\end{array}$ & $\begin{array}{l}\text { Findings suggest the importance of variety in } \\
\text { children's diet and opportunities in the prevention } \\
\text { of adolescent depression and anxiety. }\end{array}$ \\
\hline$[17]$ & $\begin{array}{l}\text { Negative associations were observed between } \\
\text { events and fruit and vegetables consumption. Overall, stress was } \\
\text { associated with a more unhealthy dietary pattern and could thus } \\
\text { contribute to the development of overweight, also in children. }\end{array}$ & $\begin{array}{l}\text { These results highlight the importance of stress } \\
\text { reduction and the related unhealthy behavior. }\end{array}$ \\
\hline$[19]$ & $\begin{array}{l}\text { Children with high scores on a 'varied Norwegian' eating pattern } \\
\text { were less likely to have indications of any psychiatric disorders } \\
\text { (adjusted OR=0.5; 95\% CI } 0.3-1.0 \text { ) and hyperactivity-inattention } \\
\text { disorders (adjusted OR }=0.4 ; 95 \% \text { CI } 0.2-0.8 \text { ) than children with low } \\
\text { scores on this pattern. }\end{array}$ & $\begin{array}{l}\text { There was a significant association between } \\
\text { eating patterns and mental health problems in } \\
\text { young adolescents, independently of physical } \\
\text { activity, sedentary activity and background } \\
\text { variables. A diverse diet rich in unrefined } \\
\text { plant foods, fish and regular meals was associated } \\
\text { with better mental health, while energy-dense, } \\
\text { nutrient-poor diets and irregular meals were } \\
\text { associated with poorer mental health. }\end{array}$ \\
\hline$[21]$ & $\begin{array}{l}\text { Children with behavior difficulties and low levels of prosocial } \\
\text { behaviors consumed fewer servings of fruit and vegetables than } \\
\text { children who did not experience any behavioral problems. Child } \\
\text { behavioral problems were associated with fruit and vegetables } \\
\text { consumption. }\end{array}$ & $\begin{array}{l}\text { Programs aimed at promoting fruit and vegetables } \\
\text { consumption in children should target those } \\
\text { families with children experiencing behavioral } \\
\text { problems. }\end{array}$ \\
\hline
\end{tabular}




\begin{tabular}{|c|l|l|}
\hline Ref No & Results & Conclusions \\
\hline$[28]$ & $\begin{array}{l}\text { The frequency of unhealthy eating behaviors in the previous year and } \\
\text { the difference between the frequency in the previous and successive } \\
\text { year were positively associated with the initiation and growth rate } \\
\text { of depressive symptoms. Depressive symptoms in the previous year } \\
\text { and the difference in depressive symptoms between the previous and } \\
\text { successive year were positively associated with the initial state and } \\
\text { growth rate of unhealthy eating behaviors. }\end{array}$ & $\begin{array}{l}\text { There is a reciprocal relationship between } \\
\text { depressive symptoms and unhealthy eating } \\
\text { behaviors. }\end{array}$ \\
\hline$[29]$ & $\begin{array}{l}\text { Sufficient fruit and vegetables intake was associated with } \\
\text { significantly decreased risk for depressive symptoms (OR: 0.21, } \\
\text { 95\% CI: 0.08-0.55). Interactive inverse associations were observed } \\
\text { between combined high physical activity and sufficient fruit and } \\
\text { vegetables intake with poor well-being (OR: 0.16, 95\%CI: 0.05- } \\
\text { 0.55) and depressive symptoms (OR: 0.12, 95\% CI: 0.03-0.48). }\end{array}$ & $\begin{array}{l}\text { High physical activity and sufficient fruit and } \\
\text { vegetables intake are inversely associated with } \\
\text { symptoms amoor we obese Chinese schoolchildren. }\end{array}$ \\
\hline
\end{tabular}

\section{DISCUSSION}

Majority of the included studies, were conducted in USA [1, 4, 5], European countries [3, 15, 17, 19], or Asian countries [14,28,29], but also in Australia [21] and Canada [16], mainly in a population of preschoolers and school-aged children $[1,4,5,15-17,19,21,29]$, but also in a general population of children [3, 14, 28]. Among the included studies, one was conducted in a specific group of obese children [29] and one in a specific group of those of American Indian ethnicity [5].

While the fruit and vegetable intake was assessed, some authors included the fruit and vegetable processed products, such as $100 \%$ juices [29], freshly squeezed fruit juices [17], but also a dried or canned ones [21], while a number of them indicated sweetened juices as a separate group [5, 15, 28]. Some authors assessed rather general dietary patterns, which included fruit and vegetables intake among other elements of it, such as 'varied Norwegian' dietary pattern (characterized by the content of fruit, vegetables, unrefined grains and fish combined with regular meals) [19], or did not include fruit and vegetables intake among other elements of it, such as 'unhealthy' dietary pattern (characterized by the content of fast food, snacks, sweetened beverages) [28].

While the mental health was assessed, the varied elements and a wide area of it were included, such as a general well-being [29], mental health [1], or emotions [17], but also a mindfulness [4], or negative issues, such as problems [17, 19], stress [3], life events [17], behavioral difficulties and problems [15, 21], as well as depressive symptoms $[5,28,29]$, or depressive symptoms combined with anxiety $[14,16]$.

In spite of the fact that a number of included studies, namely 12 studies, was relatively small, there were some coincident observations, that may indicate that for this specific population, the fruit and vegetable intake as an element of general healthy diet may be perceived as this which contributes better mental health. It was stated, that sufficient fruit and vegetables intake was associated with significantly decreased risk for depressive symptoms, but it was especially beneficial while combined with physical activity, as in such case it also promoted a better well-being [29]. It was also associated with decreased risk of behavior difficulties [21]. In general, the association was especially visible for vegetables [1] and was indicated not only for general amount of consumed fruit and vegetables, but for the obtaining a recommended 5-a-day recommendation [3].

In other studies, not only fruit and vegetables intake but the general beneficial dietary patterns were associated with the reduces mental health problems [17], lower likelihood of emotional symptoms [15], negative emotions [14], internalizing disorders [16], depressive symptoms [28], and psychiatric disorders [19].

However, it must be emphasized, that in some studies the association for fruit and vegetables intake was not statistically significant and it was not proven, that they may promote a better mental health $[4,5]$.

\section{CONCLUSIONS}

In majority of studies included to the systematic review of the observational studies analyzing the association between the fruit, vegetables and the products (including juices) intake and the mental health in pre-schoolers and school-aged children, the supposed positive influence was confirmed. However, it must be indicated that it was studied only in a few research and the issue must be analyzed in other populations. At the same time, in a number of studies, not fruit and vegetables intake alone was stated to be beneficial, but rather a more general dietary pattern, including also other elements of healthy diet and healthy lifestyle.

\section{Acknowledgements}

The study was supported by the Certified Product 'CP' Quality System (CEN.DRR.WFP.705.350. 2018. MR.3) within the National Polish Promotion Fund for Fruits and Vegetables Consumption. The funders had no role in the design of the study, in the collection, analyses, or interpretation of data, in the writing of the manuscript, or in the decision to publish the results. 


\section{REFERENCES}

1. Banta J.E., Khoie-Mayer R.N., Somaiya C.K., McKinney O., Segovia-Siapco G.: Mental health and food consumption among California children 5-11 years of age. Nutr Health. 2013;22(3-4):237-253. doi: 10.1177/0260106015599511.

2. Benton D., Young H.A.: Role of fruit juice in achieving the 5-a-day recommendation for fruit and vegetable intake. Nutr Rev. 2019;77(11):829-843. https://doi. org/10.1093/nutrit/nuz031.

3. Cartwright M., Wardle J.; Steggles N.; Simon A.E., Croker H., Jarvis M.J.: Stress and dietary practices in adolescents. Health Psychol. 2003;22(4):362-369.

4. Clevenger K.A., Pfeiffer K.A., Yee K.E., Triplett A.N., Florida J., Selby S.: Mindfulness and Children's Physical Activity, Diet, Quality of Life, and Weight Status. Mindfulness. 2018;9(1):221-229.

5. Dennison-Farris M., Sisson S.B., Stephens L., Morris A.S., Dickens R.D.: Obesogenic behaviors, self-efficacy, and depressive symptoms in American Indian children. Am Indian Alsk Native Ment Health Res. 2017;24(2):18-39.

6. Groele B., Gtabska D., Gutkowska K., Guzek D.: Influence of the socio-demographic characteristics of mothers of children aged 3-10 years on their at-home support of fruit and vegetable consumption. Rocz Panstw Zakl Hig. 2019;70(3):277-285.

7. Guzek D., Glabska D., Lange E., Jezewska-Zychowicz M.: A Polish Study on the Influence of Food Neophobia in Children (10-12 Years Old) on the Intake of Vegetables and Fruits. Nutrients. 2017;2;9(6). pii: E563. doi: 10.3390/nu9060563.

8. GuzekD., Gtąbska D., Mellová B., Zadka K., ŻywczykK., Gutkowska K.: Influence of Food Neophobia Level on Fruit and Vegetable Intake and Its Association with Urban Area of Residence and Physical Activity in a Nationwide Case-Control Study of Polish Adolescents. Nutrients. 2018;13;10(7):897. doi: 10.3390/nu10070897.

9. Hoare E., Hockey M., Ruusunen A., Jacka F.N.: Does Fruit and Vegetable Consumption During Adolescence Predict Adult Depression? A Longitudinal Study of US Adolescents. Front Psychiatry. 2018;13;9:581. doi: 10.3389/fpsyt.2018.00581.

10.Huang P., O'Keeffe M., Elia C., Karamanos A., Goff L.M., Maynard M., Cruickshank J.K., Harding S.: Fruit and vegetable consumption and mental health across adolescence: evidence from a diverse urban British cohort study. Int J Behav Nutr Phys Act. 2019;8;16(1):19. doi: 10.1186/s12966-019-0780-y.

11. Ilow R., Ptonka K., Regulska-Ilow B., Biernat J.: Assessment of fruit and vegetable intake among the population of junior high school students from Oleśnica. Rocz Panstw Zakl Hig. 2007;58(1): 237-243.

12. Jacka F.N., Kremer P.J., Berk M., de Silva-Sanigorski A.M., Moodie M., Leslie E.R., Pasco J.A., Swinburn B.A.: A prospective study of diet quality and mental health in adolescents. PLoS One. 2011;6(9):e24805. doi:10.1371/journal.pone.0024805.

13. Khalid S., Williams C.M., Reynolds S.A.: Is there an association between diet and depression in children and adolescents? A systematic review. Br J Nutr. 2016;116(12):2097-2108. doi:10.1017/ S0007114516004359.

14. Kim J.Y., Kang H.L., Kim D.K., Kang S.W., Park Y.K.: Eating Habits and Food Additive Intakes Are Associated with Emotional States Based on EEG and HRV in Healthy Korean Children and Adolescents. J Am Coll Nutr. 2017;36(5):335-341. doi: 10.1080/07315724.2017.1281774.

15. Kohlboeck G., Sausenthaler S., Standl M., Koletzko S., Bauer C.P., von Berg A., Berdel D., Krämer U., Schaaf B., Lehmann I., Herbarth O., Heinrich J., GINI-plus and LISAplus Study Groups: Food intake, diet quality and behavioral problems in children: results from the GINI-plus/LISAplus studies. Ann Nutr Metab. 2012;60:247-256.

16. McMartin S.E., Kuhle S., Colman I., Kirk S.F., Veugelers P.J.: Diet quality and mental health in subsequent years among Canadian youth. Public Health Nutr 2012;15:2253-2258.

17. Michels N., Sioen I., Braet C., Eiben G., Hebestreit A., Huybrechts I., Vanaelst B., Vyncke K., De Hen auw S.: Stress, emotional eating behaviour and dietary patterns in children. Appetite. 2012;59(3):762-769. doi: 10.1016/j.appet.2012.08.010.

18. O'Brien D., Harvey K., Howse J., Reardon T., Creswell C.: Barriers to managing child and adolescent mental health problems: a systematic review of primary care practitioners' perceptions. $\mathrm{Br} \mathrm{J}$ Gen Pract. 2016;66(651):e693-707. doi: 10.3399/bjgp16X687061.

19. Oellingrath I.M., Svendsen M.V., Hestetun I.: Eating patterns and mental health problems in early adolescence-a cross-sectional study of 12-13-year-old Norwegian schoolchildren. Public Health Nutr. 2014;17(11):255462. doi: $10.1017 / \mathrm{S} 1368980013002747$.

20. O'Neil A., Quirk S.E., Housden S., Brennan S.L., Williams L.J., Pasco J.A., Berk M., Jacka F.N.: Relationship between diet and mental health in children and adolescents: a systematic review. Am J Public Health. 2014;104(10):e31-42. doi: 10.2105/AJPH.2014.302110.

21.Renzaho A.M., Kumanyika S., Tucker K.L.: Family functioning, parental psychological distress, child behavioural problems, socio-economic disadvantage and fruit and vegetable consumption among 4-12 year-old Victorians, Australia. Health Promot Int. 2011;26(3):263-275. doi: 10.1093/heapro/daq054.

22. Ryan R., O'Farrelly C., Ramchandani P.: Parenting and child mental health. London J Prim Care (Abingdon). 2017;10;9(6):86-94.doi:10.1080/17571472.2017.1361630.

23. Schulte-Körne G.: Mental Health Problems in a School Setting in Children and Adolescents. Dtsch Arztebl Int. 2016;18;113(11):183-90. doi: 10.3238/ arztebl.2016.0183.

24. Shastri P.C.: Promotion and prevention in child mental health. Indian J Psychiatry. 2009;51(2):88-95. doi: 10.4103/0019-5545.49447.

25. Sheehan R.: Mental Illness in Children: Childhood Illness and Supporting the Family. Brain Sci. 2017;8;7(8):97. doi: 10.3390/brainsci7080097.

26. WHO. Child and adolescent mental health. Available: https://www.who.int/mental_health/maternal-child/ child_adolescent/en/ (Accessed 01.12.2019) 
27. Wissow L.S., van Ginneken N., Chandna J., Rahman A.: Integrating Children's Mental Health into Primary Care. Pediatr Clin North Am. 2016;63(1):97-113. doi: 10.1016/j.pcl.2015.08.005.

28. Wu W.C., Luh D.L., Lin C.I., Chiang Y.C., Hung C.C., Wang S., Wu C.C., Hurng B.S., Chang Y.H., Yen L.L., Chang H.Y.: Reciprocal relationship between unhealthy eating behaviours and depressive symptoms from childhood to adolescence: 10-year follow-up of the Child and Adolescent Behaviors in Long-Term Evolution study. Public Health Nutrition. 2016;19(9):1654-1665.
29. Yu H.J., Li F., Hu Y.F., Li C.F., Yang X.H., Yuan S., Huang Y., Tang B.W., Gong J., He Q.Q.: Associations of physical activity and fruit and vegetable intake with well-being and depressive symptoms among obese schoolchildren in Wuhan, China: a cross-sectional study. BMC Public Health. 2018;8;18(1):986. doi: 10.1186/ s12889-018-5779-9.

Received: 22.11.2019

Accepted: 20.12.2019 